\title{
Perspectives of social entrepreneurship in Romania in the context of the COVID-19 pandemic
}

\author{
Ruxandra ARGATU \\ Bucharest University of Economic Studies, Bucharest, Romania \\ argatu.ruxandra@gmail.com \\ Florina PUIE (RĂZVANȚĂ) \\ Bucharest University of Economic Studies, Bucharest, Romania \\ florinapuie@gmail.com
}

\begin{abstract}
The usual and rather linear functioning of a country's economic and social structures is mandatory for setting stable grounds towards wellbeing. However, disruptions may appear in the ordinary flow of a community and produce a new order of action, prompting social ecosystems to focus on core operations. The COVID-19 pandemic, that has profoundly affected humanity in 2020 on multiple channels, has imposed a novel strategic thinking both for individuals and businesses, demanding an enhanced societal approach more than ever. Faced with such a major crisis, known in literature as a "black swan" event, social enterprises must show developed capabilities, flexibility and proactivity. Given the inaccurate evidence of social enterprises activating in Romania and of the limited studies focusing on their risk-response behavior, the paper explores the impact triggered by the COVID-19 pandemic over social entrepreneurship and in particular on Romanian social enterprises. To investigate the ability of these entities to successfully cope with this groundbreaking challenge, the paper firstly performs a literature review analysis on the reorganization of the social and economic sphere, in light of the pandemic. Furthermore, it approaches the challenges posed by the pandemic on traditional and social entrepreneurship, together with their reshaping of organizational resilience. Building on literature review and on document analysis of reports regarding essential actions to be embraced to maintain stability during the COVID-19 crisis, issued by renowned consultancy companies and organizations supporting social enterprises, the paper formulates an instrument for mapping the ability of Romanian social enterprises to overcome the pandemic threats.
\end{abstract}

Keywords: social entrepreneurship, social enterprises, Romania, COVID-19 pandemic, organizational resilience, business continuity, crisis management.

\section{Introduction}

The appearance and steady rise of the COVID-19 pandemic in the early months of year 2020, has generated an unforeseen set of changes both at community scale, for individuals and businesses, as well as at the global level. To highlight these pressing matters, a report of McKinsey (2020) notes the separation between the old approach to life, before the pandemic, and the so-called "new normal", a behavioral shift from old economic and societal habits towards something previously unthought to happen in such a reduced time frame, through reverberations such as food insufficiency, companies' bankruptcy and border closure (Rambaree \& Nässén, 2020).

Two fields that are forecasted to undergo considerable shifts are the economic framework and employment, putting aside the already debated health-linked effects and social inequality (Mangan et al., 2020; Quinlan, 2020), the inability of the institutional setting being one possible cause of such deficiencies (Dunlop et al., 2020). Thus, performing persistent human capital investments is an urgent and mandatory step to be pursued (World Bank, 2020a). 
Finding the optimum course of action within a radically changing process is the most challenging, given the uncertainty context. Hence, learning and flexibility have become in such a short period of time buzzwords that will most likely direct the conduct of humanity in the long run. Regarding organizations, literature (Lai, 2018; Onea, 2020; Williams et al., 2017) also stresses the concept of resilience and the need for accurate crisis management when analyzing their response reactions to the pandemic. Through resilience, an organization is able to map the well-functioning and the poorly functioning processes and further conduct business continuity planning activities (Păunescu \& Matyus, 2020). Other instruments relevant for their wellbeing during crisis are human resource orientation expressed through an open thinking environment (Amis \& Janz, 2020) and R\&D and innovation (Roper \& Turner, 2020).

An organization's recipe for success during this challenging period is supplemented by knowledge generation and the inclusion of capabilities within its operations, to reach sustainability and market intelligence (Hamilton, 2020), combined with an adequate management of data ethics and safeguarding (Ventrella, 2020; Cognizant, 2020). To this we may also add the adherence to strategic thinking and the employment of probabilistic thinking patterns to properly manage uncertain business conditions (Brătianu, 2017). In addition, when analyzing the business impact of an event producing disruptions to an organization, it must firstly sketch the vital capabilities for employees to perform the most important business operations, find out substitute premises for conducting business and map the business collaborators and suppliers supporting the essential operations of the company (Păunescu et al., 2018). Last but not least, innovation is also to be incorporated, especially by social enterprises in Romania, to tackle rising poverty rates, educational system issues and other societal problems (Argatu, 2020).

In light of the previously stated points, the article firstly investigates the impact of the pandemic over the social and economic environment, as well as the challenges posed by the pandemic for traditional and social entrepreneurship, to understand how they have shaped organizational resilience, through literature review. Secondly, building on the literature findings and on document analysis of renowned consultancy companies' reports on the actions that must be taken by organizations to maintain stability during challenging events, more precisely the pandemic, the paper designs an instrument for mapping the ability of social enterprises in Romania to overcome the pandemic threats.

\section{Literature review}

\section{Impact of the pandemic over the social and economic environment}

The social and economic environment is a complex system subject to evolution over time, often influenced by unexpected new factors. Supposing that the social and economic contexts undergo a linear evolution and that people enjoy a qualitative living standard with no perturbations is the most desirable. Counter wise, it is also possible for humanity to meet the other side of the coin, that brings so called "extreme events" meant to challenge the status quo and force its transformation through their unpredictability (Allen et al., 2010).

The COVID-19 pandemic is by far the most notable example in this respect, associated by researchers with the "black swan" concept (Fishman, 2020; Fonseca \& Azevedo, 2020; Brătianu, 2020), respectively an occurrence simultaneously meeting three conditions: it goes beyond standardized convictions, it owns a recognizable influence and individuals attribute various causalities to it (Aven, 2015). To mitigate its effects, methods such as externalizing its consequences, altering the conduct of the system and implementing robustness may be adhered to (Nafday, 2009). 
Additionally, Antipova (2021) claims that such an event is particularly threatening the social and economic activities to a considerable extent, as many industries, for instance travel, tourism and production, or other national economic structures are already facing the unforgiving downturns imposed by the pandemic. Data-wise, HitHorizons (2020) notes that the top three operational fields of activity whose financial return was drastically reduced are the eating and drinking places, together with entertainment. The pandemic has majorly produced effects on employment and personal stability, researchers perceiving this event as a persistent catalyst for poverty and inequality in the EU space (Fana et al., 2020). A report developed by Socialsuite (2020) recognizes that the employees mainly felt the need for assistance regarding the financial area, the accessibility to basic healthcare, owning social connections and a sense of purpose in the future.

Education was also disrupted after closing down schools in the countries affected by the disease, following some negative implications of switching to online learning: resistance to change, inability of students to adapt to new practices, lack of resources for online education e.g. technology, access to internet, digital skills, or social isolation (Onyema et al., 2020).

Looking ahead in the future, a report of the World Bank (2020b) notes that the wellbeing of humanity will be seriously put at risk by the pandemic in the years to come, phenomena such as inequities and diminished inclusive development unfortunately becoming usual elements. In addition, a worldwide poverty rate placed in the 8.9-9.4\% interval is forecasted for year 2021, between 88 and 115 million people being thought to encounter poverty. In the same direction, the results of "How's Life?" 2020 report developed by OECD emphasize that poor people are more likely to be negatively affected by an economic drop, financial vulnerability and revenue instability characterizing $36 \%$ of people in OECD countries (OECD, 2020a).

Representing a catalyst for social and economic disequilibria, the pandemic is thus believed to drag down the implementation of the Sustainable Development Goals expressed by the United Nations (Berchin \& de Andrade Guerra, 2020), the addressed repairment measures needing to be highly aggregated and resilience-oriented (European Commission, 2020). Furthermore, OECD (2020b) has enhanced the need of a resilience-based systemic approach, for the recovery of the economic and social systems, and an international cooperation to overcome the crisis and to prevent future unexpected events.

\section{The challenges of the pandemic for traditional entrepreneurship and social entrepreneurship}

From an economic perspective, significant changes occurred in the business area worldwide, entrepreneurs being forced to survive this problematic situation and to adopt business continuity principles, in order to be able to perform their operations. Hence, the more well-built business continuity management an organization has, the more capable it is to counteract hazardous events, such as the COVID-19 pandemic (Păunescu \& Argatu, 2020).

It is to be claimed that the pandemic is a contest that places the resilience of organizations to very tough conditions (Bryce et al., 2020). Thus, in order to counteract the disruptions generated by the pandemic within an organization's usual procedures and practices, it must diligently use resilience, namely adjusting certain structures but at the same time keeping the stability of the main set objectives (Sakurai \& Chughtai, 2020). Additionally, setting healthy change during this troublesome period needs a deeply rooted leadership, assessing the existing status by being entrenched in reality but also with a dose of optimism, issuing proper decisions when uncertainty prevails, having a long-term planning outlook and enforcing innovation (Kaul et al., 2020; Bagwell, 2020). Besides using a proper mindset, working in a close partnership with the surrounding ecosystem, for instance other organizations and governmental entities, is largely encouraged to 
permit organizational recovery (TechnoServe, 2020). Needed to reshape the business strategy, entrepreneurs may however take advantage of some emerging opportunities, such as a higher extent of technology usage to boost productivity, considering going towards online business in a society that leans on online services and integrating social issues in the company's mission, benefitting the disrupted community after the pandemic (Zahra, 2021).

Growing concern about the pandemic impact on local communities, social entrepreneurs strive as well to continue delivering added value and to help people in need, and great importance is attributed to social entities (Ratten, 2020a). Studies show the necessity of an entrepreneurial ecosystem that could counteract unexpected events that disturb the entrepreneurship environment, based on collaborative behavior (Ratten, 2020b).

As per OECD (2020c), social entities require increased attention for their recovery, being faced with lack of financial resources, loss of volunteers due to restrictions imposed in the pandemic period and difficulty in accessing support programmes developed by the government because of their non-profit status. At the European level, certain measures assisting countries for a proper recovery of the social economy sector were implemented, respectively financial aid amounting to 700 million Euro, a Stability Fund for social enterprises and supplementary financial assistance (Philantrophy Advocacy, 2020). Regards to Romanian social economy entities, Social Economy Europe (2020) claims that they have not received any kind of supportive schemes, be them national or local ones, to assist them in better facing the consequences of the pandemic over their operations.

\section{Methodology}

Building on the previously conducted literature review, the paper aims to formulate an instrument for mapping the ability of social enterprises in Romania to get past the risks issued by the pandemic. To reach this goal, a document analysis of reports presenting essential actions to be taken by traditional and social economy organizations to maintain stability and agility during troublesome time periods such as the COVID-19 pandemic, is also performed. As for the sourcing aspect, the assessed reports constitute the point of view of renowned consultancy companies and organizations supporting social enterprises, such as Ernst \& Young, Mazars and Social Economy Europe. Concerning the time scale aspect as a selection criterion for the reports, a particular attention was given to reports elaborated in year 2020, when the COVID-19 pandemic has hit the social and economic spheres.

To gather reports rendering relevant information in supporting the research goal, several search keywords were employed, for instance "organizational resilience in the pandemic", "business continuity in the pandemic", "crisis management COVID-19", "entrepreneurship challenges COVID-19", "social entrepreneurship challenges in the pandemic", "social enterprise resilience during COVID-19”.

\section{Results and discussions}

Document analysis on reports regarding essential actions to be taken by organizations to maintain stability and agility during troublesome events

To fulfill the research goal, the paper firstly systematizes findings from reports conducted by consultancy companies and organizations supporting social enterprises, concerning the actions they should employ to make sure the stability of their operations is not put to risk during challenging times, as in Table 1. 
The main directions to which the findings of the identified reports make reference are represented by the organization's preoccupation for the welfare of its employees and addressing transformative leadership efforts in this sense; its risk approach expressed through the risk response actions employed; the management of governmental support practices to the benefit of the organization; the offering of supportive programs to employees and community beneficiaries; the undertaking of awareness-raising campaigns on social enterprises' meaningfulness for the community.

Table 1. Essential actions to be taken by organizations to maintain stability and agility during troublesome events

\begin{tabular}{|c|c|c|}
\hline Enterprise & Tackled domain & $\begin{array}{l}\text { Essential actions to be implemented to keep stability } \\
\text { in light of the pandemic }\end{array}$ \\
\hline $\begin{array}{l}\text { Traditional enterprise in the } \\
\text { start-up stage }\end{array}$ & $\begin{array}{l}\text { Financing and } \\
\text { technical support }\end{array}$ & $\begin{array}{l}\text {-identifying optimum financing sources for start-up } \\
\text { businesses, either private or governmentally-provided } \\
\text {-receiving technical support in retrieving governmental } \\
\text { assistance, managing the acquired financial resources and } \\
\text { external coaching }\end{array}$ \\
\hline Traditional enterprise & $\begin{array}{l}\text { Leadership } \\
\text { fostering business } \\
\text { resilience }\end{array}$ & $\begin{array}{l}\text {-implementing operations by staying consistent to the } \\
\text { organizational mission (organizing a command hub, } \\
\text { sustaining employees' competences, creating business } \\
\text { continuity strategies, maintaining customer engagement and } \\
\text { the interaction with the business environment) } \\
\text {-formulating a bold and motivating call to action and taking } \\
\text { quick decisions, despite the scarcity of information }\end{array}$ \\
\hline Traditional enterprise & $\begin{array}{l}\text { Leadership } \\
\text { fostering } \\
\text { crisis management }\end{array}$ & $\begin{array}{l}\text {-establishing team networks with well-defined attributions } \\
\text { (performing executive actions; setting a response on medical } \\
\text { procedures to be followed, issuing project scenarios; } \\
\text { undertaking the communication with business partners and } \\
\text { evaluating the legislative compliance degree; managing } \\
\text { technological infrastructure) }\end{array}$ \\
\hline Traditional enterprise & $\begin{array}{l}\text { Organizational } \\
\text { resilience } \\
\text { (employee } \\
\text { wellbeing, investor } \\
\text { interactions, } \\
\text { risk approach, } \\
\text { governmental } \\
\text { procedures, } \\
\text { IT, } \\
\text { legislative } \\
\text { conflicts) }\end{array}$ & $\begin{array}{l}\text {-performing employee welfare actions (health testing, } \\
\text { decontamination of the work environment, mapping novel } \\
\text { employee competences) } \\
\text {-maintaining a high degree of communication and honesty in } \\
\text { the relationship with investors by accurately managing the } \\
\text { impact degree of the pandemic on the organization } \\
\text {-conducting risk management actions and scenario } \\
\text { formulation with a great emphasis on data operations } \\
\text {-keeping a close track of the funding programs provided by } \\
\text { the government and searching alternative options to be } \\
\text { explored } \\
\text {-implementing novel technologies such as cloud and } \\
\text { cybersecurity }\end{array}$ \\
\hline Traditional enterprise & $\begin{array}{l}\text { Business } \\
\text { continuity planning }\end{array}$ & $\begin{array}{l}\text {-maintaining a timely acknowledgment of vital organizational } \\
\text { resources (personnel capabilities and processes) } \\
\text {-delineating an Internal Crisis Board, delegated to } \\
\text { disseminate particular information regarding the pandemic } \\
\text {-ensuring the safety of critical data by performing backups } \\
\text { and storing it in a safe place for further retrieval, preferably } \\
\text { not within the organization's buildings }\end{array}$ \\
\hline
\end{tabular}




\begin{tabular}{|c|c|c|}
\hline Enterprise & Tackled domain & $\begin{array}{c}\text { Essential actions to be implemented to keep stability } \\
\text { in light of the pandemic }\end{array}$ \\
\hline Traditional enterprise & $\begin{array}{l}\text { Business } \\
\text { continuity planning }\end{array}$ & $\begin{array}{l}\text {-identifying highly valuable employees that can undertake } \\
\text { their activities by keeping their existing location } \\
\text {-acknowledging the potential existence of procedures and } \\
\text { infrastructure for remote work }\end{array}$ \\
\hline Social enterprise & Crisis management & $\begin{array}{l}\text {-receiving grants to undertake business in more stable } \\
\text { conditions } \\
\text {-offering apprenticeship programs and material assistance to } \\
\text { vulnerable individuals and households in the community } \\
\text {-providing remote support, service accessibility through } \\
\text { technological solutions and assistance for remote work } \\
\text {-delivering wellbeing programs to customers and employees }\end{array}$ \\
\hline Social enterprise & Crisis management & $\begin{array}{l}\text {-allocating cash solely for critical operations and identifying } \\
\text { supplementary financing opportunities e.g. other } \\
\text { organizations } \\
\text {-undertaking personalized, one-to-one interaction with } \\
\text { employees } \\
\text {-creating support structures at the business network level, to } \\
\text { encourage individuals in being more collaborative when } \\
\text { expressing ideas } \\
\text {-implementing a trustworthy communication with all } \\
\text { categories of stakeholders by providing useful knowledge }\end{array}$ \\
\hline Social enterprise & $\begin{array}{l}\text { Organizational } \\
\text { resilience }\end{array}$ & $\begin{array}{l}\text {-operating volunteer training programs } \\
\text {-implementing training programs aimed at developing digital } \\
\text { capabilities for job-pursuers and for unemployed individuals } \\
\text {-undertaking partnerships with other social enterprises }\end{array}$ \\
\hline Social enterprise & $\begin{array}{l}\text { Endorsement of } \\
\text { post-crisis } \\
\text { recovery }\end{array}$ & $\begin{array}{l}\text {-activating encouragement of collaborative action between } \\
\text { profit-oriented organizations aimed at Corporate Social } \\
\text { Responsibility initiatives and the adherence to } \\
\text { Environmental, Social and Governance (ESG) practices }\end{array}$ \\
\hline Social enterprise & $\begin{array}{l}\text { Development of } \\
\text { the social economy } \\
\text { sector in Europe }\end{array}$ & $\begin{array}{l}\text {-participating in training programs to make public institutions } \\
\text { to be more aware of their knowledge on social enterprises in } \\
\text { policy creation processes } \\
\text {-participating in work sessions, together with the European } \\
\text { Commission, to better centralize and align the instruments } \\
\text { used in the evaluation of social enterprises' effects }\end{array}$ \\
\hline
\end{tabular}

Source: Aspen Network of Development Entrepreneurs (2020), Deloitte (2020a), Deloitte (2020b), McKinsey \& Company (2020), EY (2020), Mazars (2020), KPMG (2020), Social Enterprise UK (2020), Miller Center for Social Entrepreneurship (2020), British Council (2020), OECD (2020c), Social Economy Europe (2018).

\section{The delineation of an instrument for mapping the ability of social enterprises in Romania to overcome the pandemic's risks}

Having previously conducted the document analysis of reports assessing the measures to be addressed by organizations to counteract the disruptive effects of the pandemic, some main ideas emerge. Thus, we hold that strong efforts must be employed by social enterprises in Romania towards having a long-run view of their operations, implementing persistent actions to foster business continuity through consistent internal monitoring, undergoing collaborative efforts to maximize their degree of internal knowledge through the acquisition of other crisis management practices, and recognizing the value they have for opportunity development in the community ecosystem. 
Considering these research findings, the instrument that we sketch for mapping the ability of social enterprises in Romania to get past the pandemic's threats contains three pillars, these being organizational self-awareness, collaboration pursuits and resilience insightfulness. A graphical illustration of the instrument's pillars is constructed through Figure 1.

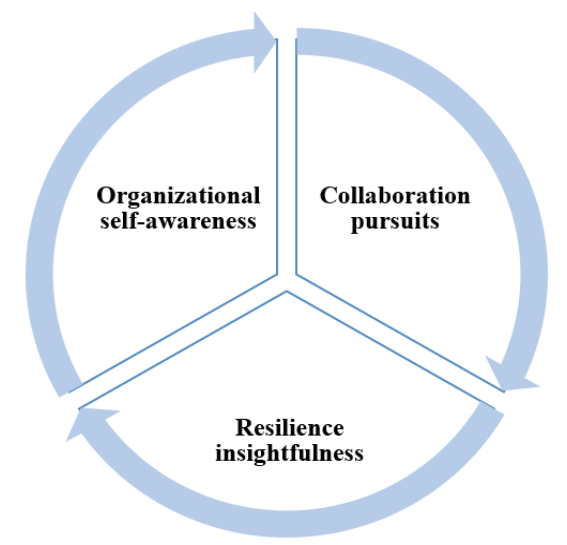

Figure 1. An instrument that maps the ability of social enterprises in Romania to overcome the pandemic's threats

Source: Authors' own research.

Concerning the very first pillar of the designed instrument, the organizational selfawareness, it sheds light over the social enterprise's understanding of the highly transformative power that it holds in creating a resilient community in face of the COVID-19 pandemic and its ability to mobilize all its internal resources to create practical added value for its beneficiaries. Regards to the second pillar, collaboration pursuits, it signals that the social enterprise is aware of the meaningfulness of business cooperation and conducts collaborative actions with other social actors from the community to strengthen its existing COVID-19 crisis management capabilities and attain supplementary knowledge. Last but not least, the resilience insightfulness pillar captures the social enterprise's employment of systematic risk evaluation procedures and retainment of business continuity by securing core structures and transformational efforts focused on learning, where required. A detailed presentation of the instrument is further provided by Table 2 .

Table 2. An instrument for delineating Romanian social enterprises' ability to overcome the pandemic's threats

\begin{tabular}{|l|l|}
\hline Component pillars & \multicolumn{1}{|c|}{ Elements } \\
\hline \multirow{1}{*}{$\begin{array}{l}\text { 1.1. The social enterprise shows a persistent focus towards the improvement of its human } \\
\text { capital's capabilities, undertaking continuous employee trainings, especially to boost their } \\
\text { digital competences for remote work. }\end{array}$} \\
$\begin{array}{l}\text { 1.2. Steady knowledge issuance actions are performed and embodied by the social } \\
\text { enterprise within its daily activities. }\end{array}$ \\
$\begin{array}{l}1.3 . \text { It properly manages data-related operations and proves consistence in respect to data } \\
\text { protection, through continuous re-checks. } \\
\text { 1.4. The social enterprise implements supportive programs for its community beneficiaries } \\
\text { in various areas e.g. professional guidance, educational support. } \\
\text { 1.5. Diligent information dissemination actions are carried out by the social enterprise to } \\
\text { stakeholders' benefit. }\end{array}$ \\
\hline
\end{tabular}




\begin{tabular}{|c|c|}
\hline Component pillars & Elements \\
\hline $\begin{array}{l}\text { 2. Collaboration } \\
\text { pursuits }\end{array}$ & $\begin{array}{l}\text { 2.1. The social enterprise conducts the recognition of its key business partners that bring } \\
\text { effectiveness to its core activities. } \\
\text { 2.2. It manifests a high degree of concern about its financial resourcefulness thus it performs } \\
\text { ongoing search efforts in order to pinpoint proper funding partners in accordance with its } \\
\text { operational needs. } \\
\text { 2.3. The social enterprise shows a considerable external outlook by mobilizing collaboration } \\
\text { with other social-purpose entities, to gather additional knowledge in respect to COVID-19 } \\
\text { crisis management. } \\
\text { 2.4. It conducts lobby actions to gather public support from the government, in operational } \\
\text { terms, and to generate consciousness on its powerful risk-mitigating capabilities. }\end{array}$ \\
\hline $\begin{array}{l}\text { 3. Resilience } \\
\text { insightfulness }\end{array}$ & $\begin{array}{l}\text { 3.1. The social enterprise addresses a radically-changing, communication-focused } \\
\text { leadership style by centralized tone-at-the-top activities to create employee urgency and } \\
\text { action awareness, together with continuous employee support. } \\
\text { 3.2. The social enterprise performs the reorganization of particular business functions that } \\
\text { are not primarily essential to the delivery of its scope. } \\
\text { 3.3. Long-term planning activities are employed. } \\
\text { 3.4. The social enterprise conducts an integrity-based investor interaction, built on } \\
\text { disclosure actions concerning the practical actions carried out to counteract the pandemic's } \\
\text { effects upon it. } \\
\text { 3.5. Business impact analysis activities are put in place by the organization in order to } \\
\text { further identify the essential actions to be adopted for continuity to be possible. } \\
\text { 3.6. Timely risk assessment activities are being implemented by the social enterprise in } \\
\text { respect to its conducted projects and actions, to undergo possible disruptive events with the } \\
\text { least amount of harm. } \\
\text { 3.7. The organization holds a proactive attitude in regards to innovation and addresses } \\
\text { investments in this sense. } \\
\text { 3.8. The social enterprise has a strong knowledge level concerning the external environment } \\
\text { and is able to seek sustainable financing means, including publicly-provided ones. } \\
\text { 3.9. There are special structures designated by the social enterprise, that are in charge with } \\
\text { managing crisis-mitigation actions. } \\
\text { 3.10. Workforce-related procedures are addressed to properly manage the division of work } \\
\text { by employees, meaning remotely or on-site. } \\
\text { 3.11. The social enterprise implements organizational learning processes and encourages } \\
\text { transformative, resilient action patterns at all levels. }\end{array}$ \\
\hline
\end{tabular}

PICBE | 1049

Source: Authors' own research.

\section{Conclusion}

The COVID-19 pandemic triggered significant changes worldwide, and the negative impact was severe in the business environment, requiring immediate decisions to counteract the emerged disruptions. Such difficult phenomena enhance the need of business continuity and resilience, as

DOI: $10.2478 /$ picbe-2021-0098, pp. 1042-1053, ISSN 2558-9652 |

Proceedings of the $15^{\text {th }}$ International Conference on Business Excellence 2021 
well as crisis management capabilities for enterprises. Having a great concern about the pandemic impact on local communities, the attention focuses on social entities that require increased effort to survive and to add value to the beneficiaries even in such a context.

Given the narrow existing literature regarding crisis management for social enterprises and of the limited studies focusing on their risk-response behavior, especially in Romania, the paper aims to scientifically contribute with developing an instrument mapping the ability to overcome the pandemic threats by these social economy entities, on three pillars. The instrument firstly focuses on organizational self-awareness, respectively recognizing its transformative power and valuing internal resources towards a more resilient community. The second pillar, collaboration pursuits, emphasizes the development of a cooperative network among social actors in the community. A third dimension refers to resilience insightfulness, based on risk assessment activities, business continuity, proactivity towards innovation and increased knowledge.

The research limitations reside in the scarcity of information constituting the basis for the instrument developed, also due to the short time scale in which the threats of the pandemic were observed, thus further research can be developed starting from the stated ideas. Additionally, implications of the research target the social entrepreneurs in Romania, and not only, that can benefit from a starting point in improving their crisis management capabilities.

\section{References}

Allen, P., Varga, L., \& Strathern, M. (2010). The evolutionary complexity of social and economic systems: The inevitability of uncertainty and surprise, Risk Management, 12, 9-30.

Antipova, T. (2021). Coronavirus Pandemic as Black Swan Event. In Antipova, T. (Ed.), Integrated Science in Digital Age 2020, 356-366, Switzerland: Springer Nature AG.

Amis, J.M., \& Janz, B.D. (2020). Leading Change in Response to COVID-19, The Journal of Applied Behavioral Science, 56(3), 272-278.

Argatu, R. (2020). Innovation capability assessment tools in social enterprises, Proceedings of the International Conference on Business Excellence, 14(1), 91-101.

Aspen Network of Development Entrepreneurs (2020). The Small and Growing Business Sector and the COVID-19 Crisis: Emerging Evidence on Key Risks and Needs, Retrieved from https://cdn.ymaws.com/ande.site-ym.com/resource/resmgr/publications/covid_and_sgbs_ issues_brief-.pdf.

Aven, T. (2015). Implications of black swans to the foundations and practice of risk assessment and management, Reliability Engineering \& System Safety, 134, 83-91.

Bagwell, J. (2020). Leading Through a Pandemic: Adaptive Leadership and Purposeful Action, Journal of School Administration Research and Development, 5(S1), 30-34.

Berchin, I.I, \& de Andrade Guerra, J.B.S.O. (2020). GAIA 3.0: Effects of the Coronavirus Disease (COVID-19) outbreak on sustainable development and future perspectives, Research in Globalization, 2, 100014.

Brătianu, C. (2017). Strategic thinking in turbulent times, Proceedings of the International Conference on Business Excellence, 11(1), 248-254.

Brătianu, C. (2020). Toward understanding the complexity of the COVID-19 crisis: a grounded theory approach, Management \& Marketing. Challenges for the Knowledge Society, 15(S1), 410-423. 
British Council (2020). Innovation and resilience: A global snapshot of social enterprise responses to Covid-19, Retrieved from https://www.britishcouncil.org/sites/default/files/socialenter prise_covidresponsesurvey_web_final_0.pdf.

Bryce, C., Ring, P., Ashby, S., \& Wardman, J.K. (2020). Resilience in the face of uncertainty: early lessons from the COVID-19 pandemic, Journal of Risk Research, 23(7-8), 880-887.

Cognizant (2020). Disruption: Data and Analytics Modernization in the COVID-19 Era, Retrieved from https://www.cognizant.com/whitepapers/disruption-data-and-analytics-modernizati on-in-the-covid-19-era-codex6298.pdf.

Deloitte (2020a). The heart of resilient leadership: Responding to COVID-19, Retrieved from https://www2.deloitte.com/global/en/insights/economy/covid-19/heart-of-resilient-leader ship-responding-to-covid-19.html.

Deloitte (2020b). The essence of resilient leadership: Business recovery from COVID-19, Retrieved from https://www2.deloitte.com/content/dam/insights/us/articles/6771_deloittereview-27/DI_Deloitte-Review-27.pdf.

Dunlop, C.A., Ongaro, E., \& Baker, K. (2020). Researching COVID-19: A research agenda for public policy and administration scholars, Public Policy and Administration, 35(4), 365-383.

European Commission (2020). Improving pandemic preparedness and management. Retrieved from https://ec.europa.eu/info/sites/info/files/research_and_innovation/groups/sam/joint opinion_improvingpandemicpreparednessandmanagement_november-2020.pdf.

EY (2020). Enterprise resilience: Nine areas of focus to reframe your future, Retrieved from https://www.ey.com/en_gl/covid-19/enterprise-resiliency-nine-areas-of-focus-for-covid19-crisis-management.

Fana, M., Pérez, S.T., \& Fernández-Macías, E. (2020). Employment impact of Covid-19 crisis: from short term effects to long terms prospects, Journal of Industrial and Business Economics, 47, 391-410.

Fishman, J. (2020). "This is Different" - The Coronavirus Pandemic as a "Transforming Event", Israel Journal of Foreign Affairs, 14(1), 3-7.

Fonseca, L.M., \& Azevedo, A.L. (2020). COVID-19: outcomes for Global Supply Chains, Management \& Marketing, Challenges for the Knowledge Society, 15(S1), 424-438.

Hamilton, J. (2020). The Strategic Change Matrix and Business Sustainability across COVID-19, Sustainability, 12(15), 6026.

HitHorizons (2020). The impact of Coronavirus on directly affected European companies, Retrieved from https://www.hithorizons.com/eu/insights/impact-of-the-coronavirus-oneuropean-companies.

Kaul, V., Shah, V.H., \& El-Serag, H. (2020). Leadership During Crisis: Lessons and Applications from the COVID-19 Pandemic, Gastroenterology, 159(3), 809-812.

KPMG (2020). Business Continuity Planning - 2019 novel coronavirus, Retrieved from https:// assets.kpmg/content/dam/kpmg/ro/pdf/2020/business-continuity-planning.pdf.

Lai, A.Y.-H. (2018). Agility amid uncertainties: evidence from 2009 A/H1N1 pandemics in Singapore and Taiwan, Policy and Society, 37(4), 459-472.

Mangan, D., Gramano, E., \& Kullmann, M. (2020). An unprecedented social solidarity stress test, European Labour Law Journal, 11(3), 247-275.

Mazars (2020). Business Continuity and Resilience Measures Through COVID 19, Retrieved from https://www.mazars.ro/Home/Insights/Task-force-and-guidance-in-response-to-COVID19/Business-Continuity-Measures-COVID-19. 
McKinsey (2020). The path to the next normal - Leading with resolve through the coronavirus pandemic, Retrieved from https://www.mckinsey.com/ /media/McKinsey/Featured\%20 Insights/Navigating\%20the \%20coronavirus \%20crisis\%20collected $\% 20$ works/Path-tothe-next-normal-collection.pdf.

McKinsey \& Company (2020). Leadership in a crisis: Responding to the coronavirus outbreak and future challenges, Retrieved from https://www.mckinsey.com/business-functions/ organization/our-insights/leadership-in-a-crisis-responding-to-the-coronavirus-outbreakand-future-challenges\#.

Miller Center for Social Entrepreneurship (2020). Navigating the Crisis - A Survival Checklist for your Enterprise, Retrieved from https://www.millersocent.org/navigating-the-crisis-asurvival-checklist-for-your-enterprise/.

Nafday, A.M. (2009). Strategies for Managing the Consequences of Black Swan Events, Leadership and Management in Engineering, 9(4), 191-197.

OECD (2020a). How's Life in 2020 Highlights. Retrieved from https://www.oecd.org/sdd/Howis-Life-2020-Highlights.pdf.

OECD (2020b). A systemic resilience approach to dealing with Covid-19 and future shocks, Retrieved from http://www.oecd.org/coronavirus/policy-responses/a-systemic-resilienceapproach-to-dealing-with-covid-19-and-future-shocks-36a5bdfb/.

OECD (2020c). Social economy and the COVID-19 crisis: current and future roles, Retrieved from http://www.oecd.org/coronavirus/policy-responses/social-economy-and-the-covid-19crisis-current-and-future-roles-f904b89f/?fbclid=IwAR2q9z6DpoVrbktD333JqiozvKorm KZF5NXBcXggWr0v7BQ6S--mk4DIlVU.

Onea, I.A. (2020). Innovation Indicators and the Innovation Process - Evidence from the European Innovation Scoreboard, Management \& Marketing. Challenges for the Knowledge Society, 15(4), 605-620.

Onyema, E., Nwafor, C., Obafemi, F., Sen, S., Atonye, F., Sharma, A., \& Alsayed, A. (2020). Impact of Coronavirus Pandemic on Education, Journal of Education and Practice, 11, 108-121.

Păunescu, C., Popescu, M.C., \& Blid, L. (2018). Business impact analysis for business continuity: Evidence from Romanian enterprises on critical functions, Management \& Marketing. Challenges for the Knowledge Society, 13(3), 1035-1050.

Păunescu, C., \& Argatu, R. (2020). Critical functions in ensuring effective business continuity management. Evidence from Romanian companies, Journal of Business Economics and Management, 21(2), 497-520.

Păunescu, C., \& Matyus, E. (2020). Resilience measures to dealing with the COVID-19 pandemic. Evidence from Romanian micro and small enterprises, Management \& Marketing. Challenges for the Knowledge Society, 15(S1), 439-457.

Philantrophy Advocacy (2020). EU COVID-19 Recovery schemes \& Policy. Retrieved from https://www.philanthropyadvocacy.eu/news/european-governments-covid-19-and-eucovid-19-recovery-schemes-policy/.

Quinlan, M. (2020). Five challenges to humanity: Learning from pattern/repeat failures in past disasters?, The Economic and Labour Relations Review, 31(3), 444-466.

Rambaree, K., \& Nässén, N. (2020). 'The Swedish Strategy' to COVID-19 Pandemic: Impact on Vulnerable and Marginalised Communities, The International Journal of Community and Social Development, 2(2), 234-250. 
Ratten, V. (2020a). Coronavirus (Covid-19) and entrepreneurship: cultural, lifestyle and societal changes, Journal of Entrepreneurship in Emerging Economies, https://doi.org/10.1108/ JEEE-06-2020-0163.

Ratten, V. (2020b). Coronavirus and international business: An entrepreneurial ecosystem perspective, Thunderbird International Business Review, 62(5), 629-634.

Roper, S., \& Turner, J. (2020). R\&D and innovation after COVID-19: What can we expect? A review of prior research and data trends after the great financial crisis, International Small Business Journal: Researching Entrepreneurship, 38(6), 504-514.

Sakurai, M., \& Chughtai, H. (2020). Resilience against crises: COVID-19 and lessons from natural disasters, European Journal of Information Systems, 29(5), 585-594.

Social Economy Europe (2018). The Future of EU Policies for the Social Economy: Towards a European Action Plan, Retrieved from https://s3platform.jrc.ec.europa.eu/documents/ 20182/313344/SEE-Action+Plan+for+Social+Economy.pdf/f81115cc-527e-4e3b-bafea8b06ab4372a.

Social Economy Europe (2020). The impact of Covid-19 on social economy enterprises, Retrieved from https://www.socialeconomy.eu.org/wp-content/uploads/2020/06/SEE-Report-Theimpact-of-COVID-19-on-Social-Economy.pdf.

Social Enterprise UK (2020). Social Enterprise and COVID-19, Retrieved from https://www. socialenterprise.org.uk/policy-and-research-reports/social-enterprise-and-covid-19/.

Socialsuite (2020). Covid-19 Social Impact Report May 2020, Retrieved from https:// socialsuitehq.com/wp-content/uploads/2020/06/Covid-19-Social-Impact-Findings-May 2020-v.2.pdf.

TechnoServe (2020). COVID-19 and Entrepreneurs in the Developing World: Supporting Business Survival and Recovery, Retrieved from https://www.technoserve.org/wp-content/uploads/ 2020/06/COVID-19-and-Entrepreneurs-Supporting-Business-Survival-and-Recovery20200601.pdf.

Ventrella, E. (2020). Privacy in emergency circumstances: data protection and the COVID-19 pandemic, ERA Forum, 21, 379-393.

Williams, T.A., Gruber, D.A., Sutcliffe, K.M., Shepherd, D.A., \& Zhao, E.Y. (2017). Organizational response to adversity: Fusing crisis management and resilience research streams, Academy of Management Annals, 11(2), 733-769.

World Bank (2020a). The Human Capital Index 2020 Update: Human Capital in the Time of COVID-19, Retrieved from https://openknowledge.worldbank.org/handle/10986/34432.

World Bank (2020b). Poverty and Shared Prosperity 2020: Reversals of Fortune, Retrieved from https://openknowledge.worldbank.org/bitstream/handle/10986/34496/9781464816024.pdf

Zahra, S.A. (2021). International entrepreneurship in the post Covid world, Journal of World Business, 56(1), 101143. 